\title{
The Creation of Life in Cultural Context: From Spontaneous Generation to Synthetic Biology
}

\author{
Joachim Schummer \\ Department of Philosophy, University of Darmstadt; js@hyle.org
}

\section{Introduction}

The artificial creation of life arises both strong fascination by scientists and strong concerns, if not abhorrence, by critics of science. What appears to be the crowning achievement of synthetic biology is at the same time considered a major evil. That conflict, which perhaps epitomizes many of the cultural conflicts about science in Western societies, calls for a deeper analysis. Standard ethical analyses, which would try to relate such conflicts to a difference in fundamental values, are difficult to apply here, because it is unclear what the underlying values of such emotions as fascination and abhorrence are. These emotions or affects, rather than just referring to what is morally right or wrong, seem to be rooted in our cultural heritage of desires and taboos of transgression.

My analysis in this paper is primarily of historical nature. By investigating ideas about the creation of life from the earliest times to the present, I aim to clarify the cultural origins of those emotions. I argue that both the fascination and the abhorrence regarding the creation of life have a common religious basis. Moreover, unlike many commentators of 19th-century mad-scientist classics, from Mary Shelley to H.G. Wells, I argue that this basis has no ancient model in religious or mythological traditions but emerged only in the 19th century from an exchange between science and religion. As long as these emotions dominate public debates, ethical deliberations about synthetic biology are likely to be neglected.

\section{Imagine a world where making life is simple}

Imagine a world where simple living organisms can easily be made from inanimate matter. Anyone can do it, provided one knows how to combine the correct ingredients in the right way. Sometimes, when the ingredients happen to occur in the right combination and context, life even emerges spontaneously. Would any scientist care about synthesizing life? Would anybody be embarrassed or concerned about someone making life? Would anybody shout, "This is presumptuous! You are trying to play God!"?

Unfortunately, it has been largely fallen into oblivion that our world was exactly like that up to the early 19th century. Spontaneous generation of life or abiogenesis, as the phenomenon was called, was taken for granted since the earliest times. It was not part of some esoteric theory. Everybody had ample evidence from ordinary experience: under favorable conditions, feces, dung, meat, straw, and so on are all perfect materials to generate different kinds of little organisms - still today some anglers make use of that to obtain their baits.

Furthermore, the Bible as well as the Talmud, the Upanishads, and many other ancient texts and scriptures are full of stories of living organisms emerging out of inanimate matter (Lippmann 1933, chap. 2). For instance, in Genesis 1, all the plants and animals are not created like Adam and Eve, they emerge out of earth, water, and air upon the creator's fiat; and in Exodus 8, the "magicians" make two of the plagues, lice and frogs, from dust and water, respectively. In almost any ancient culture, we find the notion that certain animals (mostly vermin, worms, insects, amphibians, snakes, and some birds and mammals like mice) and most plants owe their existence not to reproduction but to spontaneous generation under favorable conditions. If there was anything obscene in deliberately making such creatures as vermin, it was because nobody liked them. 
Spontaneous generation was not merely a folk myth. It was the prevailing view among scholars since antiquity. ${ }^{1}$ In the forth century BC, Aristotle had studied the different ways of how animals generate in greater detail than anybody else did before the 18th century. For those species where he could find no causal relation to parents, e.g. the unicellular (!) testa$c e a$, he considered the possibility of spontaneous generation out of nonliving matter enriched with "vital heat", i.e. a material process that was in accordance with his general chemical views. Discussing the generation of testacea, he wrote:

"Animals and plants come into being in earth and in liquid because there is water in earth, and air in water, and in all air is vital heat so that in a sense all things are full of soul. Therefore living things form quickly whenever this air and vital heat are enclosed in anything. When they are so enclosed, the corporeal liquids being heated, there arises as it were a frothy bubble. Whether what is forming is to be more or less honourable in kind depends on the embracing of the psychical principle; this again depends on the medium in which the generation takes place and the material which is included." $(\mathrm{On}$ the generation of animals, III, 11)

In contrast to Aristotle, late antique and early medieval authorities (such as Virgil, Ovid, Pliny, and Isidor of Sevilla), rather than performing their own investigations, collected the available folk knowledge and myths to build a growing standard set of views on how to make living beings. Such sets typically recommended the carcasses of cows for creating the useful bees, an art called bougonia that greatly flourished, whereas those of horses and donkeys were only able to produce wasps and beetles, respectively. Late medieval Christian authorities, such as Albertus Magnus and Thomas Aquinas, basically repeated the received views but emphasized the importance of astrological influence. ${ }^{2}$ When some Renaissance authors tried to incorporate folk myths about goose and lambs growing on trees, criticism arose, but views on the spontaneous generation of simple animals and plants remained, with few exceptions (see Section 4), largely intact through the 18th century. Francis Bacon, in his utopia New Atlantis (1628), even devised an entire research program. Starting from freshly made simple organisms, higher species should be bred that perfectly meet human needs.

"We make a number of kinds of serpents, worms, flies, fishes of putrefaction, whereof some are advanced (in effect) to be perfect creatures, like beasts or birds, and have sexes, and do propagate. Neither do we this by chance, but we know beforehand of what matter and commixture, what kind of those creatures will arise." (New Atlantis, paragr. 62)

It is important to note that there were no basic philosophical, scientific, ethical, or theological objections to both spontaneous generation and artificial creation of life. Indeed, it was perfectly reconcilable with the biblical creation myth. Religious objections could only arise after the invention of "creationism", which was provoked by various scientific developments in the 19 th century. Before discussing these events in Section 4, we need to have a brief look at another age-old topic, the creation of humanoids.

\section{Imagine a world where the creation of some humanoids is ethi- cally acceptable}

There are three rather unrelated traditions about the artificial creation of humanoids, which have nonetheless merged in many literary treatments of the topic since the 19th century: mechanical automata or androids, Kabalistic golems, and alchemical homunculi.

The first and the oldest tradition refers to mechanical devices that mimic the behavior of humans or animals. Greek mythology features at least two heroes of that art: Pygmalion

\footnotetext{
$1 \quad$ For the history of views on spontaneous generation, see Lippmann 1933 and Farley 1977.

"[...] in the case of animals generated from putrefaction, the formative power is the influence of the heavenly bodies." (Thomas Aquinas, Summa Theologiae, Pt I, q. 71)
} 
who sculptured an ivory figure of Aphrodite that was animated to become his wife Galatea; and Daedalus the ingenious artisan who is said to have built various automata. The early Greek fascination with automata was likely to be more than mere folk myth, since the 5thcentury BC poet Pindar, in his Seventh Olympic Ode, described animal-like automata placed in the streets of Rhodos for popular amusement. Ancient Greeks and Egyptians shared another fascination with "talking statues", in which hidden tubes transmitted the voice from a remote speaker, so as to animate the statues and give them authority for religious and prophetic messages. In antique Alexandria, where Greek and Egyptian cultures merged, the art of automata was perfected by the great engineers Ctesibius, Philo of Byzantium, and Hero of Alexandria, whose devices were copied and further developed by medieval Arab and, eventually, European engineers (Hill 1996, chap. 11). Such toys made a great impression on our mechanical philosophers, including Descartes, Hobbes, La Mettrie, D’Alembert, and Kant, ${ }^{3}$ particularly after the French engineer Jacques Vaucanson constructed in 1738 an almost perfect android. These philosophers all discussed whether perfect automata would be indistinguishable from natural animals, which most of them believed, and whether perfect androids would be indistinguishable from real humans, which many considered possible. However, none of them raised any ethical or religious concerns whatsoever about the mechanical manufacture of animals or humans.

The second tradition is more closely related to religion. Both the Prometheus myth and the Jewish and Christian scriptures describe the divine creation of the first human out of clay or dust. Yet, only the Jewish tradition seems to have elaborated on the theme by deriving recipes for the artificial creation of humanoids, called golems (Idel 1990; Newman 2004, pp. 183-7). The oldest text is the brief and rather cryptic Sefer Yezirah ("Book of Creation"), probably of late antique origin, which inspired not only much of the Kabalah but also many medieval and early modern Rabbis to derive various recipes for making golems. Apart from forming a human figure out of clay or dust, they all made use of the magic of certain Hebrew words and letters, the command of which should bring the golem to life or to death. The motives for making golems greatly varied. A profane one was simply the want for cheap servants for housework. According to one account, the golem would slowly grow in size turning from a servant into a threat to his creator, who would then destroy his creation by some Kabalistic magic (Scholem 1969, p. 200f.). A second, and most common, motive was to prove the magic power of the Hebrew language, which was probably the original idea of the Sefer Yezirah. For religious people, the making of golems was also a way of worshipping and seeking closeness to God by repeating his creation, which was a highly revered motive (Idel 1990, pp. xv-xvi). Yet, the golem was usually described as speechless, stupid, and inferior to humans in order to point out the difference between the human and divine creations. Only when people strived for the power of creation in order to compete with God, the making of golems was severely criticized since the 13th century (ibid., pp. 98, 149). Thus, as with mechanical humanoids, there was no ethical objection proper against the Kabalistic making (and killing) of golems.

The third tradition is related to alchemy, the forerunner of modern chemistry, and refers to the laboratory creation of homunculi. Compared to the widespread literary and artistic treatments of the topic since the 19th century, the alchemical sources in the form of explicit recipes are very rare; and even rarer are scholarly treatments of the topic, despite its utmost importance in our context. ${ }^{4}$ Indeed, much of the modern interest in homunculi seems to have arisen from misleading interpretations of the allegorical images and passages in alchemical texts that described chemical processes on the analogy of biological ones. However, there are at least three extant explicit recipes for homunculi from unknown authors that have attracted

\footnotetext{
3 Descartes: Discours de la méthode (1637), V.16; Hobbes, Leviathan (1651), Introduction; La Mettrie L'homme machine (1748); D'Alembert: “Androide" in his Encyclopédie (1758); Kant, Kritik der Praktischen Vernunft (1788), AA181.

$4 \quad$ In the following I refer mainly to the excellent analysis of Newman (2004, chap 4).
} 
the attention of alchemists and others: two early medieval Arab texts (the pseudo-Platonic Book of the Cow and a passage from the Jâbir corpus) and a Renaissance treatise famously, but probably wrongly, attributed to Paracelsus (De rerum naturae). ${ }^{5}$

The alchemical homunculus tradition shows two important characteristics that distinguish it from the other traditions of creating life and humanoids. First, the essential ingredient was male semen that, following the Aristotelian theory of sexual reproduction, required for development the material matrix of menstrual blood, which the three authors sought to replace in the laboratory with various preparations, including the use of animal organs. Hence, the theoretical basis of creating homunculi was biological rather than mechanical or Kabalistic; and it assumed that the male part was essential whereas the female part was replaceable by some preparations. Second, the goals of creating homunculi were all related to ideas of perfecting nature or divine creation, because the artificial homunculi were considered to have improved qualities over natural humans. In the Arab texts, the homunculus, either in its entirety or in dismembered form, was believed to have medical, magic, or prophetic qualities. The pseudo-Paracelsian text points out that, because the homunculus was a product of art, he was acquainted with all the secret knowledge of art. Moreover, because his generation was not "polluted" by female contact, the author considered the homunculus a higher rational being.

Medieval and early modern concerns about making homunculi were largely of theological nature. ${ }^{6}$ For instance, critics argued that the creation was comparable to the usual practice of satanic demons, who, as they believed, steeled human semen to breed giants and monsters. They argued that it was a temptation of God, who would be forced to create a new rational soul for the homunculi on demand. Furthermore, a newly created soul would lack the original sin stemming from Adam and thus undermine the predetermined religious order. Yet, the primary criticism of the making of homunculi has since early modern times always been the theological accusation of hubris, i.e. of comparing one's creative power with that of the divine creator. Like the other objections, that is not an ethical issue but a problem deeply rooted in the intricacies of the Christian religion, which suggests that man was made in the likeness of an artisan-like creator god.

The few homunculi texts became famous, if only by rumors, because their authors all considered the creation of homunculi the crowning power of alchemy in surpassing the power of Nature and even that of the divine creator. They thus considerably shaped the public image of alchemy, such that these presumptuous claims were also attributed to many other alchemists. The historical reason was that the claim of perfecting and surpassing nature was already highly debated before in the field of metallic transmutation. Indeed, any simple chemical transformation was suspected to be a presumptuous change of the divine creation against God's wills up to the 18th century (Newman 1989, Obrist 1996, Karpenko 1998, Schummer 2003a). Therefore, the homunculus could become an emblem of the hubris of alchemy altogether, which, as may be recalled, was the prototype of all laboratory sciences.

Compared to our views today, the assessments of artificial creations were almost inverted in medieval and early modern times. There were no ethical or theological objections against the creation of plants and animals, because that happened anyway all the time through spontaneous generation. Only if the creature was assumed to have a "rational soul", which some doubted even for non-European humans, a battery of theological objections were raised, from Satanism, to tempting God, to hubris. On the other hand, simple chemical transforma-

\footnotetext{
$5 \quad$ Paracelsus definitely wrote a treatise called De homunculi, which many modern authors, particularly Goethe scholars who comment on the homunculus in Faust II, have cited, obviously without reading it, because it is largely a moral treatise against sodomy rather than a laboratory manual for creating homunculi.

6 The only nontheological objection seems to be that the idea of creating of homunculi would denigrate women in human reproduction to the role of mere vessels (Newman 2004, p. 193), but that objection addressed the underlying theory rather than the practice of creating homunculi.
} 
tions unknown from ordinary experience arose strong suspicions of Satanism and hubris. ${ }^{7}$ Surprisingly, there was an almost complete ethical vacuum, and the theological surrogates excluded just the realm of (non-human) artificial life.

Against that historical background, we may assume that today's public reaction to synthetic biology are likely to refer to the two traditions of homunculi and alchemical substance transformation, rather than to those of automata and golems. However, the link to these traditions could become possible only through important developments in 19th-century biology and chemistry, which will be briefly considered in the subsequent two sections.

\section{Religion Informs Science, Science Informs Religion}

Today's creationism relies on the idea that any living being owes its existence to the primordial divine creation. It might be hard to understand for some that this idea was largely formed only in the 19th-century, and perhaps hard for others that it resulted from an exchange between science and religion. However, as long as people thought that spontaneous generation of life out of inanimate matter occurred every day, the notion that any living being owes its existence to the primordial divine creation was not very convincing.

There were alternative views to spontaneous generation since antiquity, though, most prominently the Stoic doctrine of omnipresent sperms of quasi-material pneumatic nature, out of which living beings could grow under favorable conditions. While the distinction between Aristotle's vital heat and pneumatic sperms was only a gradual and subtle one, it could make an important difference in the Christian doctrine. For instance, Augustine adopted the Stoic view and argued that all sperms were created during the primordial creation, such that any allegedly spontaneous generation was only an unfolding of the original seed of the Creator (Lippmann, 1933, pp. 23-4). However, despite some prominent followers, such as Leibniz and Buffon, that remained a minority view up to the 19th century.

Several, seemingly unrelated scientific developments worked towards the formation of modern creationism. First, late 17th-century mechanical philosophy, particularly in the hands of Boyle and Newton, was not only a scientific approach to the mechanical explanation of any phenomena, it also revived the old theological (and Islamic) idea of causal determinism, according to which any current phenomenon is the deterministic result of a chain of events that began with the primordial creation. In this natural theology, which became very popular in 18th-century philosophy and the dominant motive in natural history, anything, including any current living being, could be indirectly linked to divine creation and providence.

The second important scientific development was the increasing rigor and use of experiments in scientific studies, instead of the former collections of tales and second-hand observations. By carefully studying the anatomy and reproduction of animals and plants, which was typically motivated by natural theology, the received standard set of spontaneously generating species incrementally shrunk. Each biological species for which the reproductive mechanism was explained could thus become a candidate for primordial creation. By the time of the great 18th-century taxonomies of Linneus and his followers, in which sexual reproduction played an important role, the possible candidates for spontaneous generation were reduced to microbes, most of which remained unobservable through microscopes for another century. ${ }^{8}$ The most prominent candidates were then the so-called infusoria that appeared upon

\footnotetext{
The classical concern, which accompanied the entire history of alchemy up to the 18th century, was already formulated by the Latin church father Tertullian at the turn of the second century: If God wanted human beings to wear purple cloths, he would have created purple sheep; since he did not make purple sheep, the dyeing of wool is against God's will and therefore a sin, an alliance with Satan, as Tertullian emphasized (De cultu feminarum, I.8). See also Schummer 2003a.

The resolution of microscopes was insufficient for the observation of most microorganisms because of both chromatic and spherical aberration. A first step with achromatic compound lenses in microscopes was made in the $1830 \mathrm{~s}$, but it took further decades to solve both problems by sophisticated lens systems, such that microscopes with satisfying resolution below $1 \mu \mathrm{m}$ were commercially available probably only in the $1870 \mathrm{~s}$.
} 
the infusion of dried plants and which became the objects of rigorous experimentation since the mid-18th century. The debate around 1860 about spontaneous generation between the chemist Louis Pasteur and the biologist Felix Pouchet illustrates the level of experimental sophistication. ${ }^{9}$ In order to prove the spontaneous generation of infusoria, Pouchet heated some grass at $300^{\circ} \mathrm{C}$ in oxygen free atmosphere and transferred it through mercury into a disinfected flask that contained nothing but freshly synthesized water and oxygen. In his famously celebrated counter-proof, Pasteur demonstrated that dust could enter the flask via the mercury as a possible pathway for 'germs' of Pouchet's infusoria. And Pasteur left no doubt that his experimental rigor was based on religious motives. In his famous lecture at the Sorbonne in 1864, before the political and intellectual elite of France, he argued that the age-old idea of spontaneous generation would threaten the fundamentals of Christianity: ${ }^{10}$

"What a triumph, gentlemen, it would be for materialism if it could affirm that it rests on the established fact of matter organizing itself, taking on life of itself; matter which has in it all known forces! [...] What good then would it be to resort to the idea of primordial creation, before which mystery it is necessary to bow? Of what use then would be the idea of a Creator-God?"

In order to understand the radical religious shift towards creationism, from spontaneous generation being a banality to threatening the fundamentals of Christianity, we need to consider the third important scientific development, the theories of biological evolution, another offspring of natural theology. In Larmarck's theory of 1809, the elements that concern us here were already fully developed: He postulated an evolutionary "chain" going back from the most complex animal, the human species, to the simplest ones like worms and infusoria, which he thought arose from spontaneous generation. ${ }^{11}$ Thus, with Lamarck one could already argue that humans owe their existence to spontaneous generation. However, his evolutionary transformations were guided by a teleological principle of nature, which allowed for divine intervention, both primordial creation and continuous guiding. ${ }^{12}$ Moreover, Lamarck's ideas were soon discredited in the French Restoration, which linked spontaneous generation to materialism, atheism, and republicanism. It took another fifty years, before Darwin published his The Origin of Species (1859) in which he carefully replaced Lamarck's teleology by a causal determinism, which restored the principles of natural theology. ${ }^{13}$ Although Darwin himself avoided publicly discussing spontaneous generation (Lippmann 1933, pp. 106-7), the link to the generation of human beings was very obvious for contemporaries. Two years after the French translation of his book appeared, Pasteur explicitly made this link in the same speech cited above (ibid.):

"Take a drop of sea water [...] that contains some nitrogenous material, some sea mucus, some "fertile jelly" as it is called, and in the midst of this inanimate matter, the first beings of creation take birth spontaneously, then little by little are transformed and climb from rung to rung - for example, to insects in 10,000 years and no doubt to monkeys and man at the end of 100,000 years."

As we have seen in the previous sections, humans were the only biological species about whose creation theologians had ever been concerned before, because only they had a "rational

\footnotetext{
9 Geison 1995, chap. 5, see also Schummer 2003b.

$10 \quad$ Euvre de Pasteur, 7 vols., Paris: Masson et Cie, 1922-1939, vol II, pp. 328-346. English translation from Geison 1995, p. 111.

11 J.B. Lamarck: Philosophie zoologique (1809), vol. 1, I.6; for his views on spontaneous generation see, Lippmann 1933, p. 75, Farley 1977, pp. $41 \mathrm{ff}$.

12 "And everywhere and always the will of the sublime Author of nature and of all that exists is invariably brought about." (Ibid., vol. 1, I.4).

13 "There is grandeur in this view of life, with its several powers, having been originally breathed by the Creator into a few forms or into one; and that, whilst this planet has gone cycling on according to the fixed law of gravity, from so simple a beginning endless forms most beautiful and most wonderful have been, and are being evolved." (Origin of Species, chap. 14, final sentence).
} 
soul" that was immortal and administered by God. With Darwin's theory, the spontaneous generation of whatsoever simple organism could be seen as the first step towards the evolution of humans. The little infusoria thus challenged the core of the divine creation, the making of Adam, and thereby the core of Christian salvation and moral theology, the immortal soul imbued with original sin. One answer to that challenge was 19th-century creationism, according to which any living being owes its existence to the primordial divine creation, for which scientists like Pasteur fought with the weapons of experimental science. While today's creationists see Darwin's theory a threat to creationism, the historical order is rather inverse: Darwin's theory induced the formation of creationism because it linked spontaneous generation to the generation of humans.

\section{Synthesis of life becomes a challenge}

The controversy on the spontaneous generation of life has never been settled (Farley 1977). Rather the candidates under debate incrementally moved from bacteria to viruses, to prions and simple self-sustaining molecular systems, increasingly blurring the distinction between life and nonlife. However, the controversy's religious offspring, 19th-century creationism, changed the Christian value system, even though it remained an extremist view within the variety of Christian doctrines. For millennia the creation of living beings, from simple organisms to simple humanoids, had been no matter of religious concern, as long as no "rational soul" or demon was involved. Now, even the most rudimentary approaches to the making of life, the chemical synthesis of organic compounds, could be accused of "playing God".

As was mentioned in Section 3, alchemists had long been accused of changing the divine creation against God's will by simple chemical transformations of inorganic matter. That charge disappeared only during the 18th century based on systematic theories of chemical transformation, elements, and compounds. However, a corresponding charge came up again with the rise of 19th-century organic chemistry. As I have argued elsewhere, chemists became a target of severe criticism by hundreds of writers in many different countries (Schummer 2006a). These authors rediscovered the medieval literary figure of the 'mad alchemist' and transformed it, by attaching some moral perversion, into the modern 'mad scientist', which became the most powerful expression of the charge of hubris on contemporary chemists. To illustrate the problems that troubled 19th-century writers and the way they framed it, I quote a brief dialogue from Honoré de Balzac's novel La recherche de l'absolu (1834) between the chemist Balthazar Claes and his wife:

"I shall make metals," he cried; "I shall make diamonds, I shall be a co-worker with Nature!"

"Will you be the happier?" she asked in despair. "Accursed science! Accursed demon! You forget, Claes, that you commit the sin of pride, the sin of which Satan was guilty; you assume the attributes of God."

"Oh! Oh! God!"

"He denies Him!” she cried, wringing her hands. "Claes, God wields a power that you can never gain."

At this argument, which seemed to discredit his beloved Science, he looked at his wife and trembled.

"What power?" he asked.

"Primal force - motion," she replied. "This is what I learn from the books your mania has constrained me to read. Analyse fruits, flowers, Malaga wine; you will discover, undoubtedly, that their substances come, like those of your water-cress, from a medium that seems foreign to them. You can, if need be, find them in nature; but when you have them, can you combine them? Can you make the flowers, the fruits, the Malaga wine? Will you have grasped the inscrutable effects of the sun, of the atmosphere of Spain? Ah! Decomposing is not creating." 
"If I discover the magistral force, I shall be able to create."

When Balzac wrote his novel, in which he aimed to describe "all the efforts of modern chemistry", ${ }^{14}$ chemists were able to synthesize only a handful of organic compounds from inorganic matter. Most chemists therefore still believed in "chemical vitalism", according to which organic compounds, unlike inorganic matter, were organized by a "vital force" that was largely out of the chemical command. In the mid-19th century, however, French and German chemists started what was the biggest research project ever since: In an effort to refute vitalism, they systematically synthesized in their labs all the organic compounds anew that they had isolated before from animals and plants. ${ }^{15}$ In the period from 1844 to 1870 alone, the number of known organic compounds thus raised from about 720 to 10,700 (Schummer 1997). The project was meant to proof that the creative power of chemistry was comparable to that of "living nature". It did not stop there. As the synthetic toolbox expanded, they also produced new compounds, some of which better served human needs than natural products. The number of compounds continued to grow exponentially, from about 100,000 in 1900 to 800,000 in 1950 , to 18.5 million in 2000 , as a gigantic proof of the creative power of chemistry.

In the first half of the 20th century, when questions arose about the sense of synthesizing ever more compounds, chemists developed a meta-narrative to provide historical meaning and future orientation, in a language reminiscent of alchemy. The early phase of refuting vitalism was now called a state of "learning from nature" which was followed by a state of "rivaling and surpassing nature" in producing better compounds for human needs. The next step then should be "mastering and designing nature", or, in terms of the chemist Walden (1941, p. 49), "directing, in accordance to its conditions, the processes in the living organism and designing them for the benefit of humanity." Although the final step was frequently avoided or only indirectly hinted at, that meta-narrative became the standard model of writing stories of progress in popular histories and popularizations of chemistry as well as in official reports of chemistry and, eventually, of nanotechnology (Schummer 2006b).

It is fair to say that the chemical synthesis of life has always been in the air since the mid-19th century, both by its religious critics and literati as well as by aspiring chemists. At the latest since Aldous Huxley's Brave New World (1932), it was also an established topic in the distopian literature. For organic chemistry, on the other hand, the meta-narrative made it the ultimate and natural goal, which should provide historical meaning to the entire discipline. There was no need for chemists to mention that goal explicitly, as long as their discipline was internally flourishing and externally regarded with suspicion.

During the Cold War era, however, chemistry lost much prestige and money to its rival physics, which was heavily involved in many military-related big-science projects, from nuclear energy and weapons research, to particle accelerators, to radioastronomy and space exploration. Chemistry, on the other hand, had no such big-science project. Against that background, organic chemist Charles C. Price held his 1965 presidential address before the American Chemical Society. With an envious view on the latest "race-track accelerator", he called for "the setting of the synthesis of life as a national goal" (Price 1965). "The political, social, biological, and economical consequences of such a breakthrough would dwarf those of either atomic energy or the space program. [...] The job can be done - it is merely a matter of time and money." Explaining where all these unprecedented consequences should come from, Price claimed that the synthesis of life would lead "to modified plants and algae for synthesis

14 In a letter to Hippolyte Castille, Balzac explains, "Le héros de La Recherche de L'Absolu représente tous les efforts de la chimie moderne" (quoted from Madeleine Ambrière, Balzac et la Recherche de l'Absolu [Paris: Presses Universitaires de France, 1999], p. 401).

See Russell 1987; Bensaude-Vincent 1998, chap. 2; Bensaude-Vincent 2002, pp. 29-32; Schummer 2003a; Bensaude-Vincent 2005, chap. 2.

16 I am grateful to John Smith from Lehigh University for pointing me to this paper. 
of food, fibers, and antibiotics, to improved growth or properties of plants and animals, or even to improved characteristics of man himself."

Price's synthesis of life never became a national goal, though. One reason was probably that the President of the American Chemical Society did not shy away from provoking ethical concerns, by explicitly relating the synthesis of life "to improved characteristics of man himself", to say nothing about religious concerns. I assume that this was a deliberate, albeit unlucky, provocation, in order to catch a wide public attention to his project. Another reason certainly was that he simply failed to provide a single argument what the synthesis of life should be good for. For, all his arguments, which I have quoted above, refer to the modification rather than to the de novo synthesis of life, the proper goal of the project. Lacking any utilitarian reason, the synthesis of life project was appealing only to Price's fellow chemists. It would have demonstrated the ultimate power of chemical synthesis to the pride of chemistry and to the dismay of its religious critics.

\section{Lack of justification, lack of ethics}

There are currently a bunch of diverse research programs that are all related to synthetic biology and, more recently, to bionanotechnology. However, five of them should not be confused with the synthesis of life. The first is classical genetic engineering that modifies existing organisms on the genetic level by recombinant DNA technology, i.e. by transferring DNA sequences from one species to another. An offspring of genetic engineering, there are secondly approaches to produce modified proteins by feeding the gene expression apparatus of organisms with synthetic DNA/RNA and/or different amino acids. Both projects cannot be called synthesis of life, because they only modify or use existing organisms or parts thereof. Third, some engineers seek to employ DNA (or proteins) for digital data storage and processing, which has nothing to do with the synthesis of life. Forth, there is an offspring of Artificial Intelligence, called "Artificial Life", that develops algorithms for mathematically modeling existing or possible biological systems in order to understand their dynamics. ${ }^{17}$ The only approach that comes close to the synthesis of life is, fifth, laboratory simulations that try to mimic chemical conditions on earth several billion years ago in order to understand how the formation of organic compounds and simple pre-biotic molecular systems could have happened. ${ }^{18}$ While the first three projects typically seek justification, and support against ethical criticism, in their potentially beneficial products, the other two projects do so by referring to improved understanding.

Unlike these five projects, de novo syntheses of life consist of the following two approaches: One tries to replicate (the DNA of) a particular natural organism from scratch, as for instance a group from SUNY did with the poliovirus (Cello et al 2002). The other seeks to assemble from a tool box, which is typically derived from a variety of natural organisms, a new molecular system that complies with one or the other definition of life, including the criteria of metabolism, self-replication, and natural selection.

Compared to the other five research programs, the ambitious goal of creating life de novo usually lacks substantial justification. Although references to both beneficial products and understanding are frequently made, the arguments are not very convincing. They either rely on blurring distinctions, particularly between modifying and creating organisms, as Price already did in 1965, or refer to some undefined spin-offs. Of course one cannot deny in ad-

\footnotetext{
17 Of course, the adherents of "Strong Artificial Life" would dispute my description, claiming that their algorithms are structurally equivalent to biological systems, such that both are true forms of life but in different "media", and that writing an algorithm is creating life. I cannot comment here on these idealistic fallacies, which repeat former fallacies of AI, but refer instead to an earlier paper by Claus Emmeche (1992).

18 Strangely enough, reviews of "synthetic biology" frequently overlook that approach, although Stanley L Miller and Harold C. Urey performed already in 1953 what is considered the classical experiment on the origin of life.
} 
vance the possibility of some useful spin-offs of any research. However, that argument reminds of the Cold-War era reasoning, according to which money should be spent on certain military or prestige projects rather than on civilian research, because these projects could have some beneficial civilian spin-offs. Furthermore, in general the making of something neither presupposes nor automatically produces a deeper understanding of this something, as any chemist can tell from serendipity syntheses, although there might be exceptions. ${ }^{19}$ If understanding or beneficial products would be the goal, why not perform a research project that is tailored to that goal?

The weakness in justification for de novo syntheses of living organisms suggests that the historical motive is still important, that the leading motivation is to prove the "creative power of man", a symbolic act in the imagined rivalry with a metaphysical agency. Chemists have always called this rival "nature". Yet, as Robert Boyle already observed in 1682, that is a "semi-deity", "a kind of a goddess, with the title of nature", a substitute for the Christian god. ${ }^{20}$ Naturally that arises Christian concerns and the charge of hubris, of "playing God". It seems therefore that the scientific fascination with the creation of life and its religious abhorrence are but two sides of the same religious coin.

As I have argued in Section 4, that religious coin was largely created in the 19th century, such that both the fascination and the abhorrence have no deep roots in the Christian culture. Although constructed in response to 18th- and 19th-century scientific developments, the whole idea of "playing God" rests on the 19th-century ad-hoc assumption that any natural living being owes its existence to the divine creation. That is not only bizarre from a scientific point of view but also theologically problematic, because it contradicts almost two thousand years of theology. It would be more useful to work on a sound theology rather than drawing the emotions of fascination or abhorrence from the obscure concept of "playing God".

What is worse, however, is that we have been left with an almost complete ethical vacuum regarding the artificial creation of living organisms. Here, that it is not because "ethics is lagging behind technology", as a frequent excuse goes. On the contrary, for thousands of years people were convinced that they could create living beings, from simple organisms to humanoids, without ever bothering about any ethical issue. And as long as no rational soul was involved, that was no religious issue either. Of course, there are many modern ethical approaches to establishing respect for non-human living beings, from Jeremy Bentham's animal rights to Albert Schweitzer's "reverence for live". However, these approaches just fail to address the artificial creation of life. The only viable approach thus far seems to be consequentialism, i.e. assessing the creation of life from its prospective positive and negative consequences and with precaution regarding its possible risks. Although that is not the topic of the present chapter, I conclude with a brief ethical assessment.

Because the whole project thus far seems to lack substantial justification regarding both improved understanding and beneficial products, there is little to say in favor of it from a consequentialist point of view other than that the creators could pride themselves on their creation. On the negative side, there are predictable social costs, both by drawing research from more useful projects and by provoking a social conflict over a theologically obscure matter. Moreover, because creating does not presuppose or automatically produce understanding, the creatures carry the risks of negative impacts on the natural environment. As selfreplicating beings they must interact with their environment; and the closer their metabolism

\footnotetext{
19 For an argument to the contrary, see Benner \& Sismour (2005, p. 534) who, apart from making the usual spin-off promises, propose the triviality that making something improves the knowledge of making something. An exception might be the recent reconstruction of the Spanish flu virus from the early 20th-century pandemic, because that could by analogy improve our understanding of the current bird flu and its possible modifications.

20 Robert Boyle: A Free Inquiry into the received Notion of Nature (1682), in: The Works, ed. Thomas Birch. London, 1772, vol. 5, pp. 164, 191.
} 
is to those of natural organisms, the more will they interfere with biological systems, both on the organism and ecological levels as well as irreversibly on the evolutionary level. At the present state of biological knowledge, it is impossible to predict what the exact consequences are, but only a fool would expect that they are all beneficial. In sum, all our available ethical knowledge clearly speaks against the scientific-religious hybrid project of creating new living organisms.

\section{Conclusion}

When today's scientists are striving for the creation of life, they tend to dismiss the age-old history of creating life, because any former approach was based on erroneous views. However, from a historical point of view, it does not matter much whether former views were right or wrong from our perspective, as long as contemporary scientists were convinced they were right. What matters instead is how these views were shaped and discussed in their cultural contexts. In such a history of the idea of creating life, which I have briefly sketched in this chapter, current synthetic biology is only the latest effort that owes both its scientific motivation and mixed public reception to its prehistory.

I have argued that the crucial phase in that history was the 19th century, when the creation of life changed from being a banality to becoming both a challenge to the Christian doctrine and the implicit goal of synthetic organic chemistry. In this period of vivid exchange between science and religion, the two emotions of fascination and abhorrence emerged as two sides of the same coin, created around the scientifically and theologically obscure idea of "playing God", after emotional indifference ever since before. Since then public debates have been largely captured by these two irreconcilable emotions, such that appealing to one emotion on one side usually provokes the other emotion on the other side and vice versa. Thus, whoever tries to promote synthetic biology by appealing to the fascination of creating life is likely to provoke public protest; and whoever raises the concern of "playing God" is likely to raise somebody's fascination for doing so.

Moreover, such public debates are not only counter-productive, they also have no satisfactory ethical basis. Justifying research because it is fascinating to someone is as weak an ethical argument as criticizing research because it is abhorrent to someone else. As long as public debates are focused on these emotions, they continue to exclude ethical considerations about creating life. As I have argued throughout this chapter, there was never an ethical debate proper, not because creating life was considered impossible, but because nobody considered it an ethical issue. Instead, we have been left with an ethical vacuum about the creation of life that was filled only with quasi-moral surrogates. Since history tells us when and why these surrogates were created, we might be able to replace them with urgently required ethical deliberations.

\section{References}

Benner, S. A. \& Sismour, A. M. (2005). Synthetic biology. Nature Reviews: Genetics, 6, 53343.

Bensaude-Vincent, B. (1998). Eloge du mixte: Matériaux nouveaux et philosophie ancienne Paris: Hachette.

Bensaude-Vincent, B. (2005). Faut-il avoir peur de la chimie? Paris: Le Seuil.

Bensaude-Vincent, B. (2002). Changing Images of Chemistry. In I. H Stamhuis et al. (Eds.), The changing image of the sciences (pp. 29-42). Berlin: Springer.

Cello, J., Paul, A. V. \& Wimmer, E. J. (2002). Chemical synthesis of poliovirus cDNA: Generation of infectious virus in the absence of natural template. Science, 297, 1016-18. 
Emeche, C. (1992). Life as an abstract phenomenon: Is artificial life possible? In F. J. Varela \& P. Bourgine (Eds.), Toward a Practice of Autonomous Systems. Proceedings of the First European Conference on Artificial Life (pp. 466-474). Cambridge, MA: MIT.

Farley, J. (1977). The spontaneous generation controversy from Descartes to Oparin. Baltimore: John Hopkins UP.

Geison, G. L. (1995). The Private Science of Louis Pasteur. Princeton: Princeton UP.

Hill, D. (1996). A history of engineering in classical and medieval times. London: Routledge.

Idel, M.: (1990). Golem: Jewish magical and mystical traditions on the artificial anthropoid. Albany, NY: SUNY Press.

Karpenko, V. (1998). Alchemy as donum dei. Hyle: International Journal for Philosophy of Chemistry, 4, 63-80.

Lippmann, E. O. v. (1933). Urzeugung und Lebenskraft: Zur Geschichte dieser Probleme von den ältesten Zeiten an bis zu den Anfängen des 20. Jahrhunderts. Berlin: Springer.

Newman, W. R. (1989). Technology and alchemical debate in the late middle ages. Isis, 80, 423-445.

Newman, W. R. (2004). Promethian ambitions: Alchemy and the quest to perfect nature. Chicago: Univ. of Chicago Pr.

Obrist, B. (1996). Art et nature dans l'alchimie médiévale. Revue D'Histoire des Sciences, 49, 215-286.

Price, C. C.: (1965). The New Era in Science. Chemical and Engineering News, Sept. 27, 901.

Russell, C. A. (1987). The Changing Role of Synthesis in Organic Chemistry. Ambix, 34, 169-180.

Scholem, G. (1969). On the Kabbalah and its symbolism. New York: Schocken.

Schummer, J. (1997). Scientometric studies on chemistry I: The exponential growth of chemical substances, 1800-1995. Scientometrics, 39, 107-123.

Schummer, J. (2003a). The notion of nature in chemistry. Studies in History and Philosophy of Science, 34, 705-36.

Schummer, J. (2003b). Chemical versus biological explanation: Interdisciplinarity and reductionism in the 19th-century life sciences. Annals of the New York Academy of Science, 988, 269-281.

Schummer, J. (2006a). Historical roots of the 'mad scientist': Chemists in 19th-century literature. Ambix, 53, 99-127.

Schummer, J. (2006b). Providing metaphysical sense and orientation: Nature-chemistry relationships in the popular historiography of chemistry. In I. Malaquias, E. Homburg \& M. E. Callapez (Eds.), Chemistry, Technology and Society: Proceedings of 5th International Conference on the History of Chemistry, Estoril \& Lisbon, Portugal, 6-10 September 2005 (pp. 166-175). Aveiro: Sociedade Portuguesa de Química .

Walden, P. (1941). Geschichte der Organischen Chemie seit 1880. Berlin: Springer. 